\title{
Upper Gastrointestinal Endoscopy in Pediatric Surgical Practice
}

\author{
Pediatrik Cerrahi Pratiğinde Üst Gastrointestinal Endoskopi
}

Lutfi Hakan GUNEY, Ender FAKIOĞLU, Tugba ACER DEMIR

Başkent University Ankara Hospital, Department of Pediatric Surgery, Ankara, Turkey

\begin{abstract}
Objective: We aimed to focus descriptively and comparatively on the children with esophageal disorders requiring endoscopy: demographics, indications, methods, complications and outcomes.

Material and Methods: The records of the children with esophageal disorders indicative of endoscopy between January 2005 and February 2020 at the department of pediatric surgery of a tertiary health care center were reviewed in terms of demographic, etiological, technical aspects; including the comparison of flexible endoscopy (FE) and rigid endoscopy (RE).

Results: Endoscopy was indicated in a total of 242 children for foreign body ingestion ( $n=70,28.9 \%)$, caustic ingestion $(n=89,36.8 \%)$, esophageal stricture $(n=52,21.5 \%)$ and other rare conditions $(n=31,12.8 \%)$. Fourty two of them did not undergo endoscopy, because their caregivers did not consent. Of the rest; $102(42.1 \%)$ underwent RE, and 98 (40.5\%) underwent FE. The mean age was $36.4 \pm 35.7$ months. No statistically significant difference was detected between the mean ages of RE and FE groups ( $33.3 \pm 32.1$ vs. $33.7 \pm 24.9$ months, $p=0.918)$. Most of the patients who underwent FE were significantly males (52\% in FE group, $39.2 \%$ in RE group, $p=0.046$ ). Complication rate was $6.9 \%$ in RE group and no complication was detected in FE group $(p=0.008)$. The difference of failure rates of the groups was statistically insignificant (3.9\% in RE vs 0 in FE, $\mathrm{p}=0.066)$.
\end{abstract}

Conclusion: Both rigid and flexible endoscopy techniques are effective and safe for diagnostic or therapeutic esophageal interventions. Although each has its own advantages an disadvantages, performing rigid endoscopy takes a slightly but significantly higher risk of complication.

Key Words: Children, Endoscopy, Esophagus

\section{Öz}

Amaç: Çalışmamızda endoskopi gerektiren özofagus bozukluğu olan çocuk hastaların demografik özelliklerini, bu hastalarda rijid ve bükülebilir endoskopi endikasyonlarını, işlem komplikasyonlarını ve sonuçlarını değerlendirdik.

Gereç ve Yöntemler: Ocak 2005 - Şubat 2020 tarihleri arasında endoskopi planlanan çocukların kayıtları incelendi. Klinik veriler, endoskopi yöntemleri, sonuç ve komplikasyonlar araştırıldı. Bükülebilir endoskopi (BE) ve rijid endoskopi (RE) grupları karşılaştıııld.

Bulgular: Toplam 242 olgu saptandı. Yetmişi yabancı cisim yutma (\%28.9), 89'u kostik madde içme (\%36.8), 52'si özofagus darlığı (\%21.5) ve 31'i diğer nadir durum (\%12.8) olgularıydı. Kırk iki hastaya, onam verilmediği için endoskopi yapılmadı. Ortalama yaş 36.4 35.7 aydı. Olguların 102'sine (\%42.1) RE, 98'ine (\%40.5) BE uygulandı. Iki grubun ortalama interpretation and conclusion of the results, Taking responsibility in necessary literature review for the study. FAKIOGLU E: Taking responsibility in the writing of the whole or important parts of the study, Reviewing the article before submission scientifically besides spelling and grammar. ACER DEMIR T: Taking responsibility in patient follow-up, collection of relevant biological materials, data management and reporting, execution of the experiments.

How to cite / Atıf yazım şekli : Guney LH, Fakioglu and Acer Demir T. Upper Gastrointestinal Endoscopy in Pediatric Surgical Practice . Turkish J Pediatr Dis 2022; 16: 65-69. 


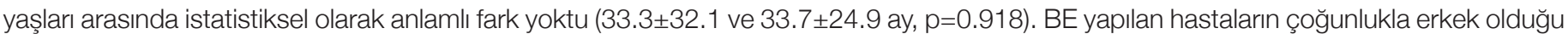
(BE grubunda \%2, RE grubunda \%39.2, p=0.046). RE grubunda komplikasyon oranı \%6.9'di ve BE grubunda ise komplikasyon yoktu $(p=0.008)$. Gruplar arasında başarısızlık oranı açısından anlamlı bir fark yoktu (RE' de \%3.9 ve BE'de 0, p=0.066).

Sonuç: Hem rijid hem de bükülebilir endoskopi teknikleri, özofagus hastalıklarında tanısal veya terapötik olarak etkili ve güvenli olarak kullanabilir. Her birine özgü avantaj ve kısıtılıklarla birlikte, rijid endoskopinin komplikasyon riski daha yüksektir.

Anahtar Sözcükler: Çocuk, Endoskopi, Özofagus

\section{INTRODUCTION}

In pediatric surgical practice; acquired, congenital or functional esophageal disorders compose a remarkable group of diseases to be managed; with their potential of becoming highly complicated, chronic, morbid problems such as persistent strictures, inefficient motility. The crucial functions of the esophagus, with its unique anatomical and physiological properties make it indispensable for an optimum quality of life. Therefore, esophageal diseases are critical, both in terms of timely diagnosis and proper treatment.

Foreign body (FB) ingestion is one of the most common and serious conditions in children who are consulted to the pediatric surgeons by emergency clinicians. For management, endoscopic FB removal under direct visualization remains the overwhelmingly accepted technique among others using bougies, Foley catheter, or magnetic nasogastric tubes $(1,2)$. Ingestion of caustic substances is an important public health problem associated with significant morbidity and mortality. For children with only vomiting or drooling and those who refuse to drink, overnight observation is routine, and endoscopy is performed only if symptoms persist and/or the child remains unable to take oral fluids. Endoscopy should be performed no later than the first 24 - 48 hours after ingestion, since wound softening later increases the risk of perforation. Injuries should be graded with the use of standardized terminology (3).

Post-operative or post-inflammatory stricutures, anatomic abnormalities, gastroesophageal reflux and achalasia comprise the other indications for endoscopy in children.

Endoscopic examination and treatment of disorders of the esophagus have taken its crucial place in surgical specialty since the introduction of the rigid endoscope (RE) by Kussmaul in 1868. The RE enabled direct visualization of the esophagus and made advanced instrumentation possible. Until the invention of the flexible endoscope (FE) in the mid-1950s, RE was the dominant modality for diagnosis and treatment of the esophageal pathologies. Today, both types of endoscopy are used with overlapping indications. However, there is no uniformly agreed or contradicted method amongst pediatric surgeons. Both procedures are accepted to be safe and effective in experienced hands. Generally the method chosen depends on the surgeon's preference The purpose of our study is to present the demographics, indications, complications and outcomes of children who have undergone rigid or flexible endoscopy in our clinic. We aimed by sharing our institutional experience of pediatric upper gastrointestinal endoscopy with a wide diagnostic spectrum, including the technical aspects; to contribute improving outcomes.

\section{MATERIAL and METHOD}

The present study was approved by the Local Ethics Committee of Başkent University Hospital, Ankara, Turkey (Project no: KA 15/49).

A retrospective review of all children admitted with diagnosis of an esophageal disorder which required rigid or flexible endoscopy between January 2005 and February 2020 in the department of pediatric surgery of a single tertiary health care center was made.

The records of the 242 children who underwent diagnostic or therapeutic FE or RE or both were reviewed.

Inclusion criterias; we included all the patients who were performed FE or RE during the mentioned period. The patients with foreign body or caustic ingestion whose caregivers did not consent the recommended endoscopy were included only for appropriate demographical analysis. Exclusion criterias; we excluded the patients on whom, other techniques (Foley catheter) were applied for esophageal FB removal.

An Olympus XP 240, 2030294 (Olympus, Japan) was used for FE. A STORZ Esophagoscope (Germany) and STORZ Optics $\left(0^{\circ}, 4 \mathrm{~mm}, 27005 \mathrm{~A}\right.$ abd $\left.30^{\circ}, 2.9 \mathrm{~mm}\right)$ were used for RE. The patient records were initially reviewed according to the diagnosis. The patients were divided into two groups according to the endoscopy technique (RE or FE). Data regarding success or failure of the procedure and complications, were examined. A failure was defined as the need to coversion of endoscopic method to the other modality to successfully achieve the esophageal diagnostic or therapeutic goal.

Demographic and clinical characteristics of the RE and FE groups were compared, using Chi-square test and Fischer's exact test where appropriate, and a t test, for categorical and continuous variables, respectively. All the analysis was computed using SPSS 24, and a p value $<0.05$ was considered statistically significant. 


\section{RESULTS}

Over the 15-year period, 242 children were admitted with esophageal conditions requiring endoscopy. Fourty two (17\%) of them were not noted to have endoscopy because their caregivers did not consent the interventions. Although we used their data to a certain extent of demographic review, we excluded them from further analysis. The demographic data of the patients who underwent upper gastrointestinal endoscopy are listed in table I.

The mean age of the group was $36.4 \pm 35.7$ months. Children younger than three years accounted for the majority (69.8\%). Females constituted $54.5 \%$ of the population with a majority of caustic ingestion (37.2\%). The 42 patients who did not undergo endoscopy were composed of 29 (69\%) FB ingestion, 13 (31\%) suspected corrosive ingestion cases. In total; 102 (42.1\%) patients underwent RE, and 98 (40.5\%) underwent FE. In four patients, conversion from RE to FE was needed. Two of those were FB, and the other two were corrosive ingestion cases. Three patients had minor complications, which were dental injury and mucosal hemorrhage.

\section{Endoscopy for Foreign body ingestion:}

The types and locations of esophageal foreign bodies are detailed in table II. A total of 70 children (37 males) ingested foreign bodies. The most commonly ingested FB was a coin $(n=23,32.8 \%)$. Other FBs impacted in the esophagus included needle, battery, plastic toy, magnet, paper clip, pebble, button and gold. Seven patients had a history of esophageal atresia and tracheoesophageal fistula (EA/TEF) repair that predisposed retention of the foreign body. Successful foreign body removal was accomplished in all of the patients.

\section{Endoscopy for Caustic Agents Ingestion:}

Out of 89 children with caustic ingestion, 55.1\% (49) were females and $44.9 \%$ (40), males. The age group who most commonly ingested a caustic agent corresponded to children younger than 3 years, who accounted for $77.5 \%$ (69) of cases (mean age 30.4 \pm 27.5 months). Thirty five (39.31\%) patients underwent RE, 41 (46.1\%) underwent FE in the first

Table I: Demographics of the study group.

\begin{tabular}{|c|c|}
\hline Characteristics & $n(\%)$ \\
\hline $\begin{array}{l}\text { Age }^{\star} \\
0-3 \text { years }{ }^{\dagger} \\
4-10 \text { years }{ }^{\dagger} \\
\text { Above } 11 \text { years }{ }^{\dagger}\end{array}$ & $\begin{array}{c}36.4 \pm 35.7(2-207) \\
169(69.8) \\
66(27.3) \\
7(2.9)\end{array}$ \\
\hline Male gender ${ }^{\dagger}$ & $110(45.5)$ \\
\hline $\begin{array}{l}\text { Esophageal conditions }^{\dagger} \\
\text { Foreign Body Ingestion } \\
{ }^{\dagger} \\
\text { Caustic Ingestion }^{\dagger} \\
\text { Esophageal Stricture }^{\dagger} \\
\text { Other }^{\dagger}\end{array}$ & $\begin{array}{l}70(28.9) \\
89(36.8) \\
52(21.5) \\
31(12.8)\end{array}$ \\
\hline
\end{tabular}

*: Mean $\pm S D$ (min.- max. months), t: n(\%)
Table II: Type and location of esophageal foreign bodies.

\begin{tabular}{l|c|}
\hline Type of foreign body $\mathrm{n}=70$ (\%) & $23(32.9)$ \\
Coin & $13(18.6)$ \\
Needle & $9(12.8)$ \\
Battery & $9(12.8)$ \\
Plastic toy & $5(7.2)$ \\
Magnet & $11(15.7)$ \\
Other & \\
\hline Type of endoscopy for FB (\%) & $17(24.3)$ \\
Rigid E. & $24(34.3)$ \\
Flexible E. & $29(41.4)$ \\
No Endoscopy & \\
\hline Location of removed FB (\%) & $23(56)$ \\
Proximal 1/3 & $7(17)$ \\
Middle 1/3 & $9(22.9)$ \\
Distal 1/3 & $2(4.1)$ \\
\hline Stomach / distal & \\
\hline
\end{tabular}

24 to 48 hours after ingestion and 13 (14.6\%) patients were observed conservatively. The ingested corrosives were alkaline substances in 60 cases (67.5\%) and acidic substances in 29 (32.5\%). Sodium hypochloride was the most commonly ingested alkaline agent; while hydrochloric acid was the most common acidic substance ingested. Figure 1 demonstrates an example for the chemical esophageal injury via FE.

\section{Endoscopy for dilatation of the esophageal strictures:}

In the study period, a total of 52 patients (33, 63.5\% females) underwent endoscopy for dilatation of esophageal strictures with a mean age of $40.1 \pm 35.8$ months. The stricture causes were; operated esophageal atresia in 35 cases, chemical burns in 16 cases, epidermolysis bullosa in one case. Dilatations were performed via RE in 29 (55.7\%), via FE in 23 (44.3\%) patients. Rigid over-the-guidewire dilators were used in all of the RE (29), and three of the FE cases. Balloon dilators were used in the remaining $20 \mathrm{FE}$ cases.

\section{Endoscopy for rare esophageal conditions:}

This group included 31 patients (21 RE, $10 \mathrm{FE}$ ). The indications for endoscopy include suspected traumatic esophageal perforation in one, suspected congenital esophageal stenosis in six, dysphagia in 10, achalasia in four, gastroesophageal reflux (GER) and suspected mucosal changes in 10 patients.

Depending upon preference of the surgeon and clinical variables of each case, either RE or FE was performed. No statistically significant difference was detected between the two groups in terms of mean age $(33.3 \pm 32.1$ vs. $33.7 \pm 24.9$ months, $p=$ 0.918). We found that most of the patients who underwent FE were significantly males (52\% of RE group, $39.2 \%$ of $\mathrm{FE}$ group, $p=0.046)$. Complication rate was significantly higher (6.9\%) in RE group, as no complication was recorded for FE group $(p=0.008)$. There was no significant difference of failure rate between endoscopic techniques $(3.9 \%$ in RE, 0 in $\mathrm{FE}, \mathrm{p}=0.066)$. Our institution's complication rate was $3.5 \%$. There was neither major complications requiring surgery, nor mortality in our study group due to endoscopy. The reasons 


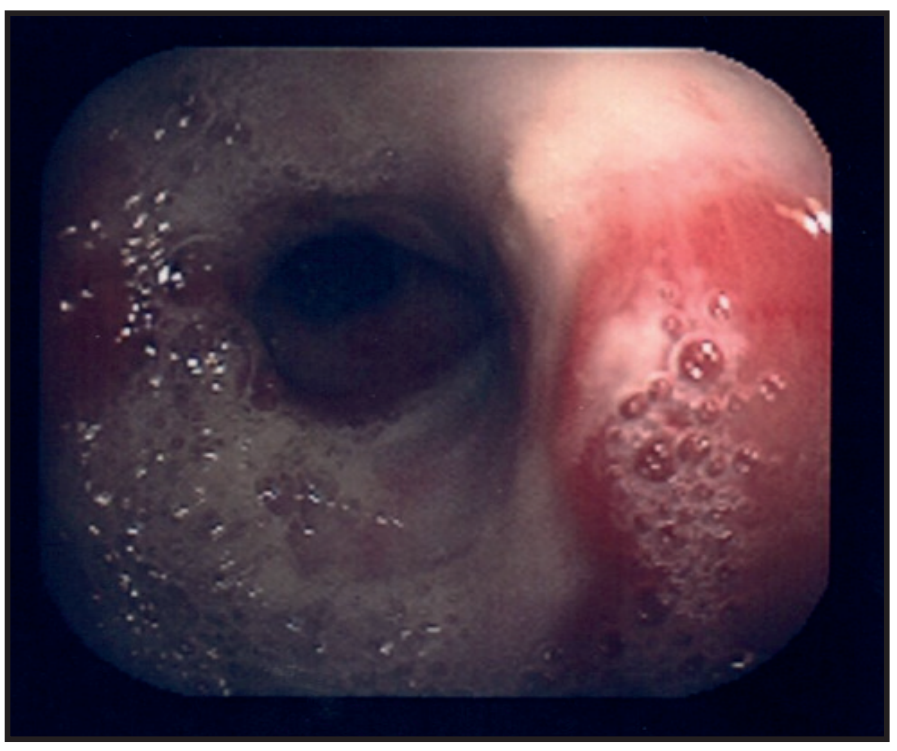

Figure 1: Chemical esophagitis.

for conversion to the other modality were most often related to difficulty of visualization with one modality, need for alternative grasping devices, and location change of the foreign body, making alternative modality more useful.

\section{DISCUSSION}

This study provides a brief overview of the conditions requiring endoscopy in pediatric surgical practice. Indications include suspected GER, dysphagia, corrosive injury, upper gastrointestinal bleeding, trauma, tracheo-esophageal fistula, strictures, percutaneous endoscopic gastrostomy, foreign body, endoscopic sclerotheraphy, variceal band ligation and anatomic abnormalies like congenital stenoses, cartilaginous rings, leiomyomas, duplications. These anatomical abnormalities are usually first identified radiographically and then confirmed endoscopically.

Most frequent indication of endoscopy in our study is corrosive substance ingestion. Accidental ingestion of corrosive compounds is reported to be more frequently observed in young children, especially those younger than the age of five (4). Our results are consistent with that, with the far lower mean age detected (30 months). Early esophageal endoscopy (during the first 24 to 48 hours) is considered a safe procedure (5). Bıçakçı et al.(6) state that they avoid from early esophagoscopy as the early esophagoscopy requires unnecessarily general anesthesia administration and this is the most fragile period of esophagus. In our clinic endoscopy is performed only if symptoms persist. Eighty five percent of our patients underwent the procedure. Thirty five patients underwent RE. We converted the RE procedure to flexible in two patients because of the insufficient visualisation of both esophagus and the stomach mucosa. Most of patients $(n=41)$ were evaluted with FE without any complications but the patients who were evaluted with RE had minor complications (two of them were dental injuries one of them was mucosal bleeding that caused insufficient visualisation). Niedzielski et al.(7) presented their study including 150 patients who were evaluted due to caustic ingestion between 1967 -2018. They performed FE for all of their patients without any complication. They suggest performing endoscopy for all patients and point out 'endoscopy is the most effective and widely used method for determining the degree of injury and planning treatment'. Similarly Balderas et al. (8) report in their retrospective study with 133 patients that all of their patients underwent fiberobtic endoscopy with no complications.

More than $98 \%$ of FB the ingestions in children are accidental (9). The ingested objects usually pass through the gastrointestinal tract without complication; however, about $20 \%$ of those were reported to require an intervention (10). When retained, esophageal FB may cause stricture, esophageal perforation, tracheoesophageal fistula, aortoesophageal fistula. Those can be mortal if the diagnosis is delayed $(11,12)$.

The treatment option is conservative in asymptomatic cases who swallowed a foreign body that goes beyond the esophagogastric junction, and the size, position, nature of swallowed foreign body and the time passed upon swallowing are also important in treatment and follow-up (13).

Russel et al. (14) studied 12 year retrospective data including 657 children: Foreign bodies were removed by FE in 56\% patients. They reported that there were no statistically significant differences between RE and FE in terms of complications, procedure length and success rate. Popel et al. (2) reported a total of 140 children with FB ingestion, 89 of which were removed via FE. They noted that both rigid and flexible endoscopy techniques are safe and effective in esophageal FB extraction. However, they remarked FE takes a substantial shorter duration compared to RE. Sink et al. (15) reported only $16 \%$ of patients underwent FE in their retrospective study group (543 children) and two patients required open surgical procedures for FB removal (15). Yan et al.(16) compared the effectiveness of RE and $\mathrm{FE}$ in the management of esophageal FB impactions in adults. The perforation rate and the need for general anesthesia were found higher in RE-associated extraction. Although FE is generally presented to be superior with higher-technology; RE still is reported to play an important therapeutic role in cases of FB impaction at upper esophagus, especially when the FB is sharp-pointed. The patient-related factors (age, clinical condition, compliance), size and sort of the FB, the impaction site, timing of impaction, and physicians' expertise are the determinants of the most appropriate management. Both FE and RE are emphasized to be effective and safe, with similar success and overall complication rates (17). 
However, the two methods have distinct advantages related to the procedure needed and the underlying pathology. The primary advantage of RE is the direct access to the area of interest. The large lumen allows for the use of a wide variety of instruments, which in turn allows for the handling and removal of larger objects under direct visualization. The direct line of instrumentation is helpful when manipulating foreign bodies.

During RE, the lumen of the esophagus is maintained by the instrument and visualization of narrow segments, the postcricoid area in particular, is made possible. RE can be performed only with general anaesthesia. The most obvious advantage of FE is superior visualization of the mucosa. The fiber technology allows for picture enhancement and offers multiple connective options such as narrow band imaging and video output. The FE has a far greater range of motion and flexibility and allows the physician to reach much further into the gastrointestinal canal, than does the rigid endoscope. FE can be performed with general anesthesia or sedo-analgesia.

Although both procedures can lead to complications such as pain, mucosal lesions, bleeding, dental injury and perforation with subsequent mediastinitis, it is well documented that the $\mathrm{RE}$ carries a greater risk than FE does $(18,19)$.

Recently non-invasive tools are started to be used for diagnosis in esophageal conditions. Gu et al. first reported a study of magnetically controlled capsule endoscopy (MCE) examination in children. They showed that MCE is feasible and safe in children older than 6 years (20). Randomized prospective studies are needed to further investigate the efficacy of endoscopy types in children. The heterogenity of our patient population, with different diagnoses, limited us to make comparisons of other variables as duration of hospitalization, operation length and the type of anesthesia The retrospective nature of this single center study is another limitation.

\section{CONCLUSIONS}

Both rigid and flexible endoscopy techniques are effective and safe for diagnostic or therapeutic esophageal interventions. However, performing rigid endoscopy takes a slightly but significantly higher risk of complication.

\section{REFERENCES}

1. Gmeiner D, von Rahden BH, Meco C, Hutter J, Oberascher G, Stein HJ. Flexible versus rigid endoscopy for treatment of foreign body impaction in the esophagus. Surg Endosc 2007;21:2026-9.

2. Popel J, El-Hakim H, El-Matary W. Esophageal foreign body extraction in children: flexible versus rigid endoscopy. Surg Endosc 2011;25:919-22.

3. Hoffman RS, Burns MM, Gosselin S. Ingestion of Caustic Substances. N Engl J Med 2020;382:1739-48.
4. Fallahi S, Hosseini SMV, Fallahi S, Salimi M, Hesam AA, Hoseini SH. Extent of injury of gastrointestinal tract due to accidental ingestion of chemicals among children at Bandar Abbass Children Hospital 2009-2011. Life Sci J 2012;9:2054-8.

5. Temiz A, Oguzkurt P, Ezer SS, Ince E, Hicsonmez A. Long-term management of corrosive esophageal stricture with balloon dilation in children. Surg Endosc Other Interv Tech. 2010;24: 2287-92.

6. Bicakci U, Tander B, Deveci G, Rizalar R, Ariturk E, Bernay F, et al. Minimally invasive management of children with caustic ingestion: less pain for patients. Pediatr Surg Int 2010; 26: 251-5.

7. Niedzielski A, Schwartz SG, Partycka-Pietrzyk K, MielnikNiedzielska G. Caustic Agents Ingestion in Children: A 51-Year Retrospective Cohort Study Ear Nose Throat J 2020;99:52-7.

8. Barrón Balderas A, Robledo Aceves M, Coello Ramírez P, García Rodríguez E, Barriga Marín JA. Endoscopic findings of the digestive tract secondary to caustic ingestion in children seen at the Emergency Department. Arch Argent Pediatr 2018;116:40914.

9. Kramer RE, Lerner DG, Lin T, Manfredi M, Shah M, Stephen TC, et al. Management of ingested foreign bodies in children: a clinical report of the NASPGHAN endoscopy committee. J Pediatr Gastroenterol Nutr 2015;60:562-74.

10. Eisen GM, Baron TH, Dominitz JA, Faigel DO, Goldstein JL, Johanson JF,et al. Guideline for the management of ingested foreign bodies. Gastrointest Endosc 2002; 55:802-6.

11. Russell RT, Cohen M, Billmire DF. Tracheoesophageal fistula following button battery ingestion: successful non-operative management. J Pediatr Surg 2013; 48:441-4.

12. Litovitz T, Whitaker N, Clark L, White NC, Marsolek M. Emerging battery-ingestion hazard: clinical implications. Pediatrics 2010;125:1168-77.

13. Tiryaki T, Akbıyık F, Şenel E, Mambet E, Livanelioğu Z, Atayurt H. Foreign Body Ingestion in Childhood. Turkish J Pediatr Dis 2010; 4: 94-9.

14. Russell R, Lucas A, Johnson J, Yannam G, Griffin R, Beierle E, et al. Extraction of esophageal foreign bodies in children: rigid versus flexible endoscopy Pediatr Surg Int 2014;30:417-22.

15. Sink JR, Kitsko DJ, Mehta DK, Georg MW, Simons JP. Diagnosis of Pediatric Foreign Body Ingestion: Clinical Presentation, Physical Examination, and Radiologic Findings. Ann Otol Rhinol Laryngol 2016;125:342-50.

16. Yan XE, Zhou LY, Lin SR, Wang Y, Wang YC. Therapeutic Effect of Esophageal Foreign Body Extraction Management: Flexible versus Rigid Endoscopy in 216 Adults of Beijing. Med Sci Monit 2014;20:2054-60.

17. Ferrari D, Aiolfi A, Bonitta G, Riva CG, Rausa E, Siboni S, et al. Flexible versus rigid endoscopy in the management of esophageal foreign body impaction: systematic review and metaanalysis. World J Emerg Surg 2018;13:42.

18. ASGE Standards of Practice Committee, Ikenberry SO, Jue TL, Anderson MA, Appalaneni V, Banerjee S, et al. Management of ingested foreign bodies and food impactions. Gastrointest Endosc 2011;73:1085-91.

19. Wennervaldt K, Melchiors J. Risk of perforation using rigid oesophagoscopy in the distal part of oesophagus. Dan Med J 2012; 59: A4528.

20. Gu Z, Wang Y, Lin K, Wang X, Cheng W, Wang L, et al.Magnetically Controlled Capsule Endoscopy in Children: A Single-center, Retrospective Cohort Study J Pediatr Gastroenterol Nutr 2019;69:13-17. 